\title{
Psycholinguistic Peculiarities of Contextual Realisation of Concept «MACHT» in Linguistic and Cultural Space of German's*
}

\section{Психолінгвістичні особливості контекстуальної реалізації концепту «МАСНТ» у мовно-культурному просторі німців**}

Olesia Skliarenko ${ }^{1}$

Ph.D. in Philology,

Assistant Professor

\section{Олеся Скляренко ${ }^{1}$}

кандидат філологічних наук, доцент

E-mail: lesiaskliarenko82@gmail.com orcid.org/0000-0003-3412-6560

Аліна Акімова ${ }^{2}$

кандидат філологічних наук, доцент
Alina Akimova ${ }^{2}$

Ph.D. in Philology,

Assistant Professor

E-mail: a alina09@ukr.net orcid.org/0000-0001-7546-2902

ResearcherID C-5824-2017

Oksana Svyrydenko ${ }^{1}$

Ph.D. in Philology,

Assistant Professor
Оксана Свириденко ${ }^{1}$ кандидат філологічних наук, доцент

E-mail: lo.svyrydenko@ukr.net orcid.org/0000-0001-9287-5768

\footnotetext{
* The research was conducted as part of DAAD project «East - West Dialogue» (ID: 57457363).

** Дослідження виконане в рамках проекту DAAD «Діалог Схід - Захід» (ID: 57457363).
} 
Психолінгвістичні особливості контекстуальної реалізацї̈...

${ }^{1}$ Pereiaslav-Khmelnytskyi

Hryhorii Skovoroda State

Pedagogical University

$\triangle$ 30, Sukhomlynskyi Str.,

Pereiaslav-Khmelnytskyi, Kyiv Reg.,

Ukraine, 08401

${ }^{2}$ Interregional Academy

of Personnel Management

2, Frometivska Str., Kyiv,

Ukraine, 203039
${ }^{1}$ ДВНЗ «Переяслав-

Хмельницький державний педагогічний університет імені Григорія Сковороди»

$\checkmark$ вул. Сухомлинського, 30, Переяслав-Хмельницький, Київська обл., Україна, 08401

\author{
${ }^{2}$ Міжрегіональна Академія \\ управління персоналом \\ вул. Фрометівська, 2, Київ, \\ Україна, 203039
}

Original manuscript received December 12, 2018

Revised manuscript accepted August 31, 2019

\begin{abstract}
Research actuality has determined the necessity to study the peculiarities of contextual realization of the concept "MACHT» in German communicative and cultural area by means of using the results of free associative experiment and contextual analysis of proverbs and aphorisms that made it possible to find out value preferences and priorities of Germans.

The purpose of the article is to identify psycholinguistic peculiarities of the concept "MACHT» in German communicative and cultural area by comparing the results of contextual analyses of proverbs and aphorisms based on the results of free associative experiment.

To describe the results of linguistic material we used such methods as semantic cognitive concept modeling which allowed us to identify macro models and describe the frame model of the concept "MACHT» organization which we present as a chainorganized structure: the concept "MACHT», macro frame "MACHT UND GESELLSCHAFT» and subframes "MACHT UND DAS POLITISCHE», "MACHT UND DAS SOZIALE» "MACHT UND DAS HÄUSLICHE». To find out the psycholinguistic peculiarities of conceptual realization we have used the methodology of free associative experiment.

The findings of the conducted analysis reveal that the concept "MACHT» is manifested in German communicative and cultural area as the subframes "MACHT UND DAS POLITISCHE», "MACHT UND DAS SOZIALE» "MACHT UND DAS HÄUSLICHE», where a typical representative of power is characterized by valuable possibilities to direct other, have respect, prosperity and some social characteristics, such as: medical insurance, social help in case of unemployment, possibility to implement himself/herself into society while having the refuges status or being a single parent, have the right to have holidays and free time, the right for sexual preferences. Valuable marker is very important here as it forms axiological personality marker of self-esteem and reflects in reaction of free associative experiment in nominations and markers of private properties, authority and keeping one's own face in front of society and lifestyle.
\end{abstract}


Psycholinguistic Peculiarities of Contextual Realisation of Concept...

Conclusion. In this way the general prototype of an ideal power subject is seen as an ethnic and cultural carrier of the German linguistic and cultural studies concerning the power subject, its communicative behavior, personal features necessary for successful result of power object, his/her appearance and social state.

Key words: lexeme, semantic, concept, power, German language culture, subframe, contextual realization, free associative experiment.

\section{Вступ}

У сучасних психолінгвістичних дослідженнях сьогодення виявляється посилений інтерес до проблем взаємодії індивідуальної мови людини та міжкультурної комунікації, впливу етнокультурних, соціальних та психологічних чинників на мовленнєві процеси, що пояснюється відкриттям нових можливостей для аналізу сфери мовної свідомості, співвідношення мови й особистості. Екстралінгвістичні фактори у тісній взаємодії з ментальною структурою суспільства зосереджують на собі увагу багатьох науковців.

Таким чином, вбачаємо доцільним вивчення психолінгвістичних особливостей контекстуальної реалізації концепту «МАСНТ» у мовно-культурному просторі німців, адже це дасть нам можливість виявити ціннісні настанови та пріоритети, тому що такі дані $€$ універсальними та онтологічно релевантними як для мовної особистості, так і для нації у цілому.

У рамках дослідження феномену владних відносин ми не повинні виключати 3 поля зору особливості культури німецької етнічної спільноти. Це дасть нам можливості окреслити їх характерні риси та ціннісні орієнтири.

Ізраїльський психолог Ш. Шварц (Schwartz \& Bilsky, 1990), аналізуючи ціннісні домінанти культур на індивідуальному рівні, виділив 10 базових характеристик культури для аналізу індивідуальної шкали цінностей представника певної культури. До базових цінностей ним було віднесено такі: безпека (Security), конформність (Conformity), традиція (Tradition), доброзичливість (Benevolence), універсалізм (Universalism), самостійність (Selfdirection), стимуляція (Stimulation), гедонізм (Hedonism), досягнення (Achievement) та влада (Power). 
Інтерес для нашого дослідження становлять два останні ціннісні орієнтири. Під досягненням Ш. Шварц (Schwartz \& Bilsky, 1990) вбачав два типи рис: по-перше, для особи важливо демонструвати всім свої здібності, вона прагне, щоб нею захоплювалися, подруге, для особи значимим є власний успіх, вона сподівається на визнання своїх досягнень іншими. Влада як ціннісний орієнтир має два трактування: по-перше, влада визначається як можливість для людини бути заможною, а також мати повагу з боку оточуючих та керувати іншими, по-друге, влада як ціннісний показник індивіда формує аксіологічну категорію самоствердження (Yang, Malt \& Srinivasan, 2017).

На разі ми маємо зауважити, що для поглибленого аналізу психолінгвістичних особливостей контекстуальної реалізації концепту «МАСНТ» у мовно-культурному просторі німців нами було використано теорію фреймової семантики лінгвокультурних концептів, що дасть можливість систематизувати класти інформації про певний фрагмент реальності та виявити фреймові інваріантні структури. Аналізований концепт «МАСНТ» є динамічним фреймом у якому експліцитно присутня наочна картина типової поведінки німців, що дає можливість правильно інтерпретувати іiі відповідно до категорій стереотипності та не стереотипності. Фреймова модель концепту «МАСНТ» відображає впорядковані ланцюжки дій та відповідні їм системи об’єктів, суб'єктів та інструментів, які реалізуються у вигляді слотів (Гайдученко, 2008).

Таким чином етноспецифічний представник німецької лінгвокультури може охарактеризувати фреймову модель концепту «МАСНТ» у такому ланцюжці:

кониелт «MACHT» ----- макрофрейм «MACHT UND GESELLSCHAFTLICHE BEZIEHUNGEN» ------- субфрейми «MACHT UND DAS POLITISCHE», «MACHT UND DAS SOZIALE» «MACHT UND DAS HÄUSLICHE».

Основними рисами, які утворюють ці цінність за Ш. Шварцом П. Молер та К. Вон (Mohler \& Wohn, 2005) називають такі: соціальна влада, власність, авторитет, збереження обличчя в очах громадськості, соціальне визнання та побут. Показник «влада та соціальне» в німецькій шкалі цінностей визначений на рівні середнього значення для європейських культур. Натомість за показником «влада та політика» ФРН посідає одне 3 перших місць 
Psycholinguistic Peculiarities of Contextual Realisation of Concept...

в Європі (Thomas, 1993). Таким чином, носії німецької культури у владних відносинах вбачають передусім аспект особистого самоствердження.

Залучивши доробки з психолінгвістики, типології культур, розроблені в сучасній культурології та культурній антропології, ми визначили етноспецифічні особливості когнітивних смислів концепту «МАСНТ» в проекції на німецьку культуру. На основі дослідження когнітивних смислів за запропонованим 3.Д. Поповою та Й.А. Стерніним методом семантико-когнітивного моделювання концептів (Попова \& Стернин, 2007) ми визначили макромодель та описали польову організацію концепту «МАСНТ», що дозволило визначити етнокультурну специфіку аналізованого концепту в німецькій лінгвокультурі.

Мета дослідження - виявлення психолінгвістичних особливостей концепту «МАСНТ»у мовно-культурному ареалі німців на основі зіставлення контекстів паремій та афоризмів, та вільного асоціативного аналізу.

\section{Методи й методики дослідження}

Для досягнення поставленої мети у статті використано методику семантико-когнітивного моделювання концептів, що дає нам змогу визначити макромоделі та описання фреймової моделі організації концепту «МАСНТ», яка полягає у ланцюжці концепту «МАCHТ», макрофрейму «МACHT UND GESELLSCHAFT» та субфреймів «MACHT UND DAS POLITISCHE», «MACHT UND DAS SOZIALE» «MACHT UND DAS HÄUSLICHE». Для визначення психолінгвістичних особливостей контекстуальної реалізації цього концепту в мовно-культурному просторі німців нами було використано методику вільного асоціативного експерименту. Вільний асоціативний експеримент був проведений у період з 01.07.2019 по 11.07.2019 у рамках виконання проекту DAAD «Ost West Dialog». Такий тип експерименту полягає у тому, що випробовуваного не обмежують у виборі можливих асоціацій. Цей експеримент дав можливість встановити додаткові риси суб'єкта влади в межах функціонування субфреймів «МACHT UND DAS SOZIALE», «MACHT UND DAS POLITISCHE», а також «MACHT UND DAS 
HÄUSLICHE». Теоретико-методологічними підгрунтями слугували роботи С. Засєкіна (2012), В. Петренка (1997), Л. Спиридонової (2015), I. Стерніна (Стернин, 2017), В. Обера та Г. Шенона (Ober \& Shenaut, 2006).

У вільному асоціативному експерименті взяло участь 35 німецькомовних респондентів, які живуть та навчаються у м. Магдебург, із них: за віковими критеріями: студенти від 22 до 34 років; за гендерним критерієм: 32 жінки та 3 чоловіків, що дало цікаві результати в моменті дослідження рольової репрезентації жінки, як суб'єкта влади в субфреймі «MACHT UND DAS HÄUSLICHE»; за географічним критерієм - жителі ФРН.

Усього було опрацьовано по 102 реакції для субфреймів «MACHT UND DAS POLITISCHE» та «MACHT UND DAS HÄUSLICHE», при цьому більш значна частина реакцій 110 актуалізує смислові зв'язки субфрейма «МАCHT UND DAS SOZIALE», що пояснюється тим, що респонденти є студентами напрямку «соціальна робота».

\section{Результати та дискусії}

Зважаючи на той факт, що етнокультурний компонент концепту пов'язують 3 особливостями процесів категоризації та концептуалізації, які здійснюються на основі співвіднесення 3 наявними в ментальному просторі прототипами, методом опису ми визначили прототипові характеристики основних учасників владних відносин відповідно до запропонованої Дж. Лакоффом та М. Джонсоном (2008) типології прототипів.

Найбільш повно в проаналізованих реакціях вільного асоціативного експерименту та на засадах контекстного аналізу пареміологічних та афористичних текстів представлений когнітивний смисл «Macht als Teilnehmer». Він об'єктивується майже в третині реакцій та досліджуваних контекстів текстів.

У переважній більшості випадків концепт «МАСНТ» експлікується через основного реалізатора владних відносин суб'єкта влади в межах макрофрейму «MACHT UND GESELLSCHAFT». У субфреймі «MACHT UND DAS POLITISCHE» на основі вільного асоціативного експерименту та контекстного 
аналізу представлено такі номінації основних суб'єктів влади: політик (der Politiker), депутат (der Abgeordnete), можновладець (der Machthaber), голова уряду, канцлер (der Regierungschef, der Bunderskanzler) та службовець (der Beamte). В афористичному фонді суб'єктами влади найчастіше мисляться: владні особи (die mächtigsten Menschen, die Mächtigen), політик (der Staatsmann), законодавець (der Gesetzgeber), король (der König), владні особистості (die führenden Persönlichkeiten), клас (die Klasse), уряд (die Regierung), тиран (der Tyrann), не ті (die Falschen), добрі (die Guten), боягузи (die Feigen), дурні (die Dummen, dumme Leute), наставник (der Meister), партія (die Partei), вагома людина (der Mann von Bedeutung), диктатор (der Diktator), погонич (der Treiber), міністр (der Minister), верховенство (die Obrichkeit), керівник (der Leiter), слабкі (die Schwachen), князі (die Fürsten), більшість (die Majorität). У пареміологічному фонді субфрейми «МАСНТ UND DAS SOZIALE» та «MACHT UND DAS POLITISCHE» часто чітко не розмежовують i представлені, наприклад, такими номінаціями суб'єктів владних взаємовідносин: пан (der Herr), святий (der Heilige), багатий (der Reiche), великий пан (der große Herr), правитель (der Regent), князь (der Fürst), кайзер (der Kaiser), властитель (der Mächtige), папа римський (der Papst), найвищі (die Obersten), управитель (der Meister). У субфреймі «MACHT UND DAS HÄUSLICHE» учасників владної взаємодії диференціюють за гендерною ознакою і суб'єктом влади вбачають в основному чоловіка (der Mann).

Відповідно до результатів вільного асоціативного експерименту найчастішими асоціаціями респондентів у субфреймі «МACHT UND DAS POLITISCHE» є депутат (der Abgeordnete) - 17,0\% реакцій та партія (die Partei) - 16,0\% реакцій, за ними слідує реакція коаліція (die Koalition) - 14,0\% та канцлерка (die Kanzlerin) - 14,7\%. Слід відмітити також такі реакції у аналізованому субфреймі як: меншість (die Minderheit) - 12,7\%, біженці (die Flüchtlinge) $8,8 \%$ та дебати (die Debaten) - 6,8\% усіх досліджуваних реакцій. Цікавим тут є також той аспект, що реакція біженці є новою для німецької лінгвокультури, та характеризує певну соціальну зміну демократичного суспільства ФРН. Що ж до реакції меншість, то така реакція вже стала абсолютною нормою німецькомовного 
суспільства, у якому вже з 2015 року дозволені одностатеві шлюби та усиновлення такими парами дітей.

Спектр реакцій субфрейму «МACHT UND DAS SOZIALE» відповідно до вільного асоціативного експерименту характеризується найбільшим наповненням, респондентами було надано аж 110 реакцій, у той час як інші субфрейми - реакціями у кількості 102. Тож найбільш вживаними асоціаціями суб'єкта влади у цьому субфреймі є: студент (der Student) - 19,0\%, бідний (der Arme) $12,0 \%$, багатий (der Reiche) - 11,0\%, на соціальній субсидії (mit Sozialhilfe) - 11,0\%, при цьому було зазначено, що це саме соціальні субсидія типу Hartz IV, яку отримують саме безробітні, та яка не включає у себе пенсійного забезпечення. Велике значення надається медичному страхуванню (die Medizinversicherung) - 12,0\%, безробітній (der Arbeitslose) - 9,0\%, біженець (der Flüchtling) $8,0 \%, 3$ інвалідністю (der Behinderte) - 7,0\%, той, хто харчується із соціального столу (der Eine, der aus der Tafel ist) - 5,0\%, мати одиночка (die alleinerziehende Mutter) - 4,0\% та батькоодинак (der alleinerziehende Vater) - 2,0\%. За результатами можна стверджувати, що субфрейм «МACHT UND DAS SOZIALE» отримує нові конотації в сучасному суспільстві ФРН, де молоді люди переймаються питаннями безробіття, медичним страхуванням, біженцями та бідністю, яка стала надзвичайно яскраво виражатися у Східній Німеччині, та не є властивою німецькій спільноті.

У субфреймі «MACHT UND DAS HÄUSLICHE» учасниками владної взаємодії $є$ не лише чоловіки, як це було за аналізом пареміологічних та афористичних текстах, а й жінки. Взагалі обсяг номінацій реакцій дав наступний показник - чоловік (der Mann) 24,0\%, жінка (die Frau) - 24,0\%, рівність (die Gerechtigkeit) - 30,0\%, діти (die Kinder) - 5,0\%, робота (die Arbeit) - 8,0\%, відпустка (der Urlaub) - 7,0\% та вільний час (die Freizeit) - 2,0\%. Наведена палітра номінацій респондентів $є$ набагато багатшою, та показує основні цінності суспільства ФРН, що полягають у рівності.

Із наведених номінацій суб' єкта влади зібраного у ході вільного асоціативного експерименту та взятого з контекстуального аналізу пареміологічних та афористичних текстів слід звернути увагу на такі національно специфічні особливості концепту «МАСНТ». По-перше, номінація суб'єктів влади здійснюється за виконуваною ними соціальною функцією (наприклад, правитель (der Regent), 
міністр (Minister) та ін.), зрідка за соціальним становищем (зокрема, верховенство (die Obrichkeit), багатий (der Reiche), в основу поодиноких номінацій покладено особисті характеристики суб'єкта (як от: боягузи (die Feigen), слабкі (die Schwachen)).

По-друге, суб'єкт влади мислиться в переважній більшості випадків як одна особа, рідше як група уповноважених осіб, хоча вільний асоціативний експеримент додає сюди такі поняття, як більшість, меншість та коаліція, що пояснюється політичним становищем Німеччини зараз, де відбувається зміна коаліції та керівників найбільш вагомих партій, що пов'язано 3 останнім періодом перебування канцлерки Ангели Меркель на своїй посаді.

На основі контекстуальних дослідження пареміологічних та афористичних текстів німецької лінгвокультурної спільноти за принципами прототипної семантики в межах когнітивного смислу «Macht als Teilnehmer» можна ідентифікувати прототип суб'єкта влади. У німецькій картині світу прототип суб'єкта влади специфікують за двома основними типами, згідно з класифікацією прототипів Дж. Лакоффа та М. Джонсон (2008). Так, у німецьких пареміях та афоризмах відтворено прототип соціального стереотипу учасника влади та прототип ідеального учасника влади. Прототип соціального стереотипу учасника владної взаємодії це ословлений узагальнений типовий образ учасника влади, відтворений 3 урахуванням етноспецифічних аксіологічних та когнітивних принципів в межах досліджуваного соціо-культурного простору. Прототип ідеального діяча владної взаємодії мислять як бажаний, взірцевий вербально відтворений образ учасника влади, сформований на основі певної етнокультурної традиції. У зв'язку 3 тим, що влада в німецькій лінгвокультурі виступає як суб'єктнооб'єктна форма взаємовідносин, це дає змогу описати національно специфічний прототип суб'єкта влади та прототип об'єкта влади (Hoffman, Lambon, Ralph \&Rogers, 2013).

Прототип соціального стереотипу суб'єкта влади в межах когнітивного смислу «Macht als Teilnehmer» визначають за особливостями здійснення професійних обов'язків. По-перше, діяльність суб'єкта влади німці вважають малорезультативною (Witze, 2019) «Hast Du schon gehört, auch Politiker sollen... jetzt nach Leistung bezahlt werden?» - «Aber das ist doch unmenschlich, die ganze Bundesregierung verhungern zu lassen!»), яка характеризується 
Психолінгвістичні особливості контекстуальної реалізаиї̈...

відсутністю відповідальності (Politiker, 2019; Witze, 2019) Früher haben die Regierungschefs noch Verantwortung getragen Heute tragen sie Boss!).

По-друге, типового політика як стереотип суб'єкта влади пов'язують в німецькій лінгвокультурній спільноті з неправомірними вчинками: вбивствами, обігом незаконних грошей, нехтуванням інтересів народу, зловживанням наданими повноваженнями на власну користь: (Zitate, Sprüche, 2019) Es gibt Staubsaugervertreter, die verkaufen Staubsauger. Es gibt Versicherungsvertreter, die verkaufen Versicherungen. Und dann gibts noch die Volksvertreter...! Соціальний стереотип суб'єкта влади осмислюється німцями у зв'язку зі здійснюваними ним свавільними вчинками (Zeh, 2019) Herren und Narren tun, was sie wollen); бездіяльністю, ледарством (Zitate zum Thema «Macht», 2019) Fürsten und Esel tun nichts ungetrieben); перебуванням під сильним впливом своїх помічників (Wander, 2019) Fürsten und Herren dürfen nicht weiter sehen, als ihre Hofbedienten erlauben). Окрім того, в пареміологічних та афористичних текстах фіксуємо негативну оцінку великої кількості керівників, які здійснюють владу: (Wander, 2019) Eine Obrigkeit, gebratene Äpfel und den Schnupfen findet man überall.

До основної діяльності стереотипу суб'єкта влади німці відносять його комунікативну поведінку. Так, передбачається, що керівник повинен стежити за своєю мовою та змістом свого повідомлення, він часто говорить неправду: (Witze zum Thema «Politik und Gesellschaft», 2019) Stöhnt der Psychiater: «Also, Herr Abgeordneter, ich kann Ihnen nicht helfen, wenn Sie immer nur mit kein Kommentar antworten...»; (Zitate, Sprüche, 2019) Kinder und Narren sagen die Wahrheit. Politiker ... sind weder das eine noch das andere. Окрім того, прототип соціального стереотипу суб'єкта влади мислиться як такий, що багато і беззмістовно говорить: так, парламент у Німеччині довгий час називали «Schwatzbude», тобто «приміщення, де марнословлять» (Гайдученко, 2008).

Серед основних особистих рис прототипу соціального стереотипу суб'єкта влади представники німецької лінгвокультури виокремлюють такі переважно негативні якості: відсутність розумових здібностей для здійснення суб'єктом своє діяльності (Zitate, Sprüche, 2019) Niemand muss ein Vollidiot sein, um Politiker $\mathrm{zu}$ werden, aber es erleichtert die Sache ungemein! Sponti-Sprüche); 
грубість, відсутність поваги та розуміння в ставленні до підлеглих (Witze zum Thema «Politik und Gesellschaft», 2019) Unser Chef hat ein Herz aus Gold, nur härter); низький морально-етичний рівень, що проявляється в непорядності, безбожжі, злості (Zitate zum Thema «Macht», 2019) Ein frommer Fürst ist ein seltsamer Vogel); неприйнятна удаваність, облуда, гонор (Zitate, Sprüche, 2019) Der Blick der Menschheit war bisher zu stumpf, zu erkennen, daß die mächtigsten Menschen große Schauspieler waren. F.Nietzsche); нещирість (Zitate zum Thema «Macht», 2019) Der Mächtige steckt den andern in den Sack); суб'єкт влади характеризується як непослідовний, а його прихильність швидко минає (Zitate, Sprüche, 2019) Grosser Herren und schöner Frauen Liebe hat Sonnenart, sie fällt sobald auf einen Kuhdreck, als auf ein Rosenblatt).

За зовнішнім портретними характеристиками прототип соціального стереотипу суб'єкта влади наділяється надмірною вагою (Zitate, Sprüche, 2019) Lieber einen dicken Chef, als ein dünnes Gehalt) та дорогим одягом.

За своїм соціальним статусом прототип соціального стереотипу суб'єкта влади визначається німцями як фінансово забезпечена особа (Witze zum Thema «Politik und Geellschaft», 2019) Wer den Daumen auf dem Beutel hat, hat Macht. (Zitate, Sprüche, 2019), яка має певну свободу від підпорядкування (Zitate, Sprüche, 2019) Bewundern wir Wehrlosen deshalb einen Mächtigen so sehr, weil sie dem Weltgesetz, wie Marionetten von fremder Hand gelenkt zu werden, nicht unterliegen? (Zitate, Sprüche, 2019).

Окрім того, прототип соціального стереотипу суб'єкта влади пов'язують в пареміях та афоризмах із не тією особою: (Witze zum Thema «Politik und Gesellschaft», 2019) Es sind meist die Falschen, die an die Macht kommen. Aber sie kommen nur deshalb dorthin, weil die Richtigen nicht so danach drängeln. (Witze zum Thema «Politik und Geellschaft», 2019). А змінити чи покращити суб'єкта влади в німецькому мовно-культурному просторі не мислиться можливим: (Witze zum Thema «Politik und Geellschaft», 2019) Obrichkeit ändern und Obrichkeit bessern sind zwei Dinge soweit von einander wie Himmel und Erde. (Zitate, Sprüche, 2019). Відтак, німці завчасно дають суб' єктові влади негативну оцінку: (Zitate, Sprüche, 2019) So viel Herren, so viel Zähren; so viel Honig, so viel Gall; so viel Freuden, so viel Leiden, so ist's hier und überall. Разом 3 тим, у пареміях 
перевага віддається новому суб'єктові перед старим (Zitate, Sprüche, 2019) Neue Herren und neue Schuhe hat man lieber als die alten), однак застерігають, що з новим уводяться нові закони, приходять нові підлеглі (Zitate, Sprüche, 2019).

У досліджуваній лінгвокультурі категоризація прототипу суб'єкта влади здійснено 3 урахуванням гендерного фактору. У пареміологічних текстах німецької лінгвокультури в межах субфрейму «MACHT UND DAS HÄUSLICHE» жінку визначають здебільшого як об'єкт влади її чоловіка: (Witze zum Thema «Politik und Gesellschaft», 2019) Die Frau ist dem Manne ein Pflaster und er ist ihr Paster (Hirt). Жінками керувати досить складно (Witze zum Thema «Politik und Gesellschaft», 2019) Ein Weib ist schwerer zu regieren als ein Volk), хіба що жінка розумна. Однак справжній чоловік, на думку німців, зобов'язаний керувати/управляти дружиною та дитиною: (Zitate, Sprüche, 2019) Wer Weib und Kind nicht regieren kann, ist nicht einmal ein halber Mann. Разом 3 тим, гарна дружина може бути вагомим доповненням чоловіка, вона коронує його честь: (Zitate, Sprüche, 2019) Eine gute Frau ist des Mannes Ehrenkrone. Німці вважають також, що взаємодія між чоловіком та дружиною повинна грунтуватися не на підпорядкуванні, а на рівноправному союзі між ними: (Zitate, Sprüche, 2019) Man muss seiner Frau Gesellschafter und seiner Knechte Herr sein.

Разом 3 тим, рольова репрезентація жінки як суб'єкта влади не заперечується повністю представниками німецької лінгвокультури. У пареміологічних текстах констатують, що, з одного боку, жінки повсякчас прагнуть влади, а 3 іншого, хочуть підкорятися. Мають владу над чоловіками лише багаті жінки, що й засуджується: (Zitate, Sprüche, 2019) Ich nahm mir eine Frau mit Vermögen und gab ihr dafür die Herrschaft im Haus. Над чоловіком влада жінки досить умовна і проявляється через контроль над його почуттями та гумором: (Zitate, Sprüche, 2019) Das Weib beherrscht den Mann durch Liebe (Milde, Sanftmuth). При здійсненні влади жінки керуються почуттями, а чоловіки розумом: (Zitate, Sprüche, 2019) Die Frau regiere Herz und Topf, der Mann den Becher und den Kopf. Власне керівництво жінки німці засуджують, пов'язуючи його з діяннями нечистої сили, тому не вбачають його перспективним ані для сім'ї, ані для держави: (Zitate, Sprüche, 2019) Wo regiert das Spinnrad, da steht es schlimm um Haus und Staat. 
Psycholinguistic Peculiarities of Contextual Realisation of Concept...

Прототип ідеального суб'єкта влади за вільним асоціативним експериментом та контекстуальним аналізом пареміологічних та афористичних текстів наділяється низкою бажаних рис, здійснює очікувані вчинки, що повинно забезпечити максимальний результат від владної взаємодії з точки зору концептуалізанта. Щодо здійснення прототипом ідеального суб'єкта своєї діяльності, то для німців важливо, щоб кількість уповноважених здійснювати владу була виправданою (Zitate zum Thema «Macht», 2019) Eine Regierung, die maßlos wird, setzt sich gegen sich selbst in Aufstand und Widerspruch, und nach kürzem Taumeln spricht sie sich das eigene Urteil. J. von Görres); а влада безликої більшості сприймається ними негативно (Zitate zum Thema «Macht», 2019) Nichts ist widerwärtiger als die Majorität: denn sie besteht aus wenigen kräftigen Vorgängern, aus Schelmen, die sich accomodiren, aus Schwachen, die sich assimilieren, und der Masse, die nachtrollt, ohne nur im mindesten zu wissen was sie will. (W.J. Goethe «Maximen und Reflexionen» Zitate zum Thema «Macht», 2019); суб’єкт повинен мати надійних радників, однак очікується, що правитель має здійснювати владу одноосібно (Zitate zum Thema «Macht», 2019) Ein Fürst braucht dreierlei Leute: geleh Zitate, Sprüche, 2019rte Männer zum Regiment, beherzte zum Kriege und fürsichtige zur Hoffhaltung; (Zitate, Sprüche, 2019) Zweien Herren in einem Land und zweien Narren in einem Hause vertragen sich nimmermehr).

По-друге, під час здійснення владних повноважень німці передбачають, що суб'єкт чітко знає поле поширення своєї влади, в межах якого його дії залишаються легітимними: (Zitate zum Thema «Macht», 2019) Ist der Herr im Haus, ist er König; ist er hinaus, gilt er gar wenig; правління має забезпечувати суб'єкту соціальне визнання, повагу, довіру з боку підлеглих, а тому воно має бути справедливим (Zitate zum Thema «Macht», 2019) Der Kaiser soll Kaiser sein, so lange er recht tut); обов'язок суб'єкта вбачається в допомозі, годуванні та захисті підлеглих, лише в цьому випадку керівник буде Спасителем, батьком та рятівником (Zitate, Sprüche, 2019) Die Obrigkeit soll drey Ämter und drey Namen führen; sie soll helfen, nähren, wehren, und soll heissen: Heiland, Vater, Retter); особливо цінується помірне використання влади іiі носієм: (Zitate, Sprüche, 2019) Macht besitzen und nicht ausüben ist wahre Größe. F. Beutelrock. 
Психолінгвістичні особливості контекстуальної реалізацї̈...

У пареміях та афоризмах завдання керівника бачиться в навчанні підлеглих організовувати самих себе: (Zitate, Sprüche, 2019) Welche Regierung die beste sei? Diejenige, die uns lehrt, uns selbst zu regieren. J.W. Goethe. Самоконтроль у німецькій культурі це частина особистої автономії та самовизначення, які грунтуються на готовності нести відповідальність за власні вчинки. М. Ріхтер називає внутрішній контроль (internalisierte Kontrolle), прямим виявом якого вважає саморегулювання та самоорганізацію, одним із семи німецьких культурних стандартів, які визначають специфіку сучасної культури (Richter, 2005).

Щодо комунікативної поведінки, в німецькій лінгвокультурі прототип ідеального суб'єкта влади постає мовчазним, він не має права виправдовуватися, повинен діяти, а не бути предметом обговорень (Zitate, Sprüche, 2019) Woran erkenn' ich den besten Staat? - // Woran du die beste Frau kennst - // daran, mein Freund, daß man von beiden nicht spricht. F. Schiller «Votivtafeln»); бажаний керівник повинен також мало, але чесно говорити, бути справедливим, послідовним, ощадливим (Zitate, Sprüche, 2019) Ein Fürst soll fünf Eigenschaften haben: Gerecht im Richten, wahrhaftig im Reden, beständig im Handeln, verschwiegen in Rathschlägen und mild im Geben). Німці допускають, що керівник має право використовувати покарання (Zitate, Sprüche, 2019) Die Obrigkeit muss strafen wie der Vater das Kind), однак не помсту, і не зловживати примусом (Zitate zum Thema «Macht», 2019) Ein Regent muss wissen, wie er faule und böse Zähn ohne zwangen könne aussreissen).

Із особистих рис найвагомішими з точки зору етноспецифічного представника німецької лінгвокультури визначаються такі позитивні якості: терпіння (Zitate zum Thema «Macht», 2019) Wer leicht die Geduld verliert, verliert leicht die Macht. E. van der Strabten Sternberg); співчуття, відповідальність та уважність до підлеглих (Zitate zum Thema «Macht», 2019) Man kann sagen, dass drei Qualitäten vornehmlich entscheidend sind für den Politiker: Leidenschaft Verantwortungsgefühl - Augenmaß. M.Weber); розум, щедрість, талан (Zitate, Sprüche, 2019) Eine Obrigkeit soll haben drei Stück: Weisheit, Grossmuth und Glück); хитрощі (Zitate, Sprüche, 2019) Ein Fürst, der noch so tüchtig ist, bedarf zur Macht auch noch die List).

Для німців важливо, щоб суб'єкт враховував бажання підлеглих (Zitate, Sprüche, 2019) Wenn der Fürst kein Ohr hätte, 
die Untertanen zu hören, so hätte er keinen Kopf, sie zu regieren); а його морально-етичні принципи переважали його інтелектуальні здібності (Zitate, Sprüche, 2019) Die moralischen Qualitäten der führenden Persönlichkeiten sind für eine Generation und für den Lauf der Geschichte vielleicht von noch größerer Bedeutung als rein intellektuelle Leistungen. (A. Einstein Zitate, Sprüche, 2019). Німці очікують також, що суб'єкт буде до міри суворим: (Zitate, Sprüche, 2019) Landgraf, werde hart! W.Gerhard. С. Шроль-Махль із посиланням на Richter В. зазначає, що історія Німеччини, світові війни, поділ країни, «посилили прагнення стабільності та порядку, а також сильного керівництва, яке б було в змозі позбутися цих страхів» (Richter, 2005: 87).

Прототиповий ідеальний німецький суб'єкт влади вирізняється також прагненням діяти, а не мати, бути, а не здаватися: (Zitate, Sprüche, 2019) Die guten Mächte sagen: Ich will schaffen und sein; die bösen sagen; Ich will haben und scheinen. W. Rathenau. Відтак, гарною владою визнається та, яка $є$ дієвою, однак іiі не чують: (Zitate, Sprüche, 2019) Eine gute Obrigkeit ist eine Uhr, die zeigt und nicht schlägt.

У німецькій лінгвокультурі прототип ідеального суб'єкта влади характеризується за його належним зовнішнім виглядом, зокрема: (Zitate, Sprüche, 2019) Was macht Angela Merkel eigentlich mit Ihren alten Klamotten? Ganz einfach: Sie trägt sie!

\section{Висновки}

Отже, за результатами досліджень, психолінгвістичні особливості контекстуальної реалізації концепту «МАСНТ» у мовно-культурному просторі німців можна поділити за трьома субфреймами: «MACHT UND DAS POLITISCHE», «MACHT UND DAS SOZIALE» та «MACHT UND DAS HÄUSLICHE», які узагальнюють психолінгвістичне усвідомлення німцями кожного iз субфреймів специфічними реакціями на номінації, що їх представляють.

Загальний образ прототипу ідеального суб'єкта влади мислиться етноспецифічним носієм німецької лінгвокультури у зв'язку 3 безпосередньою діяльністю суб'єкта влади, його 
комунікативною поведінкою, особистими рисами, необхідними для результативного здійснення влади, та зовнішнім виглядом та соціальним станом.

Перспективним вбачається подальший психолінгвістичний аналіз інших субфреймів на об'єкт влади у німецькому суспільстві iз застосуванням комп’ютерної програми ПЛ аналізу LIWC 2015.

\section{Література}

Гайдученко, Л.В. (2008). Дериваційне поле концепту Macht (влада) в німецькомовній картині світу. Проблеми семантики, прагматики та когнітивної лінгвістики, 13, 74-80.

Засєкін, С. (2012). Психолінгвістичні універсалії перекладу художнього тексту. (Монографія). Луцьк.

Лакофф, Д., \& Джонсон, М. (2008). Mетафоры, которыми мы живем. Москва: ЛКИ.

Магун, В.С., \& Руднев, М.Г. (2007). Жизненнье иенности населения Украинь в европейском контексте. Retrieved from https://polit.ru/research/\%20 2007/07/16/10values.html\%20\# ftn5

Петренко, В. (1997). Основы психосемантики. Москва: МГУ.

Попова, З.Д., \& Стернин, И.А. (2007). Когнитивная лингвистика. Москва: АСТ: Восток-Запад.

Спиридонова, Л. (2015). Асоціативний експеримент як засіб дослідження образу світу. Наука і освіта, 1, 152-158.

Стернин, И.А. (2017). Лексикографическое представление психолингвистического значения слова. Вестник РУДН, 15(2), 204-214. https://doi.org/10.22363/23132264-2017-15-2-204-214

Hoffman, P., Lambon, R., Matthew, A.R., \& Timothy, T. (2013). Semantic diversity: A measure of semantic ambiguity based on variability in the contextual usage of words. Behavior Research Methods, 45(3), 718-730. https://doi.org/10.3758/ s13428-012-0278-X

Mohler, P., \& Wohn, K. (2005). Persönliche Wertorientierungen im European Social Survey. ZUMA-Arbeitsbericht, 2005(01), 21 [in German].

Ober, B.A., \& Shenaut, G.K. (2006). Semantic memory. In M.J. Traxler \& M.A. Gernsbacher (Eds.), Handbook of Psycholinguistics (pp. 403-455). New York: Academic Press. https://doi.org/10.1016/B978-012369374-7/50012-2

Richter, M. (2005). Kommunikative Konflikthandhabung. Wirtschaftskybernetik und Systemanalyse. Band 24. Interkulturelle Kooperation. Wissenschaftliche Jahrestagung der Gesellschaft für Wirtschafts- und Sozialkybernetik vom 6. und 7. Oktober 2005 in Greifswald. Berlin: Duncker \& Humbolt [in German].

Resch, B. (1991). Kulturstandards lernen und vermitteln. Kulturstandards in der interkulturellen Begegnung (pp. 71-102). Saabrücken: Breitenbach [in German].

Schwartz, S.H., \& Bilsky, W. (1990). Toward a Theory of the Universal Content and Structure of Values: Extensions and Cross-Cultural Replications. Journal of Personality and Social Psychology, 58, 878-891. https://doi.org/10.1037/00223514.58.5.878 
Thomas, A. (1993). Kulturvergleichende Psychologie. Göttingen: Hogrefe [in German].

Wander, K. Deutsches Sprichwörter-Lexikon. Ein Hausschatz für das deutsche Volk. Retrieved from https://www.zeno.org/Wander-1867/A/Macht?hl=macht [in German].

Willis Witze. Politiker. Retrieved from https://www.willis-witze.de/Politiker-Witze/ Uebersicht-50,1.html [in German].

Witze zum Thema «Politik und Gesellschaft». Retrieved from http:// www.hahaha.de/ witze/politik-gesellschaft [in German].

Yang, Xu, Malt, C.B., \& Srinivasan, M. (2017). Evolution of word meaning through metaphorical mapping: Systematicity over the past millennium. Cognitive Psychology, 96, 41-53. https://doi.org/10.1016/j.cogpsych.2017.05.005

Zeh, K. Christliche Werte - Menschliche Politik. Retrieved from http:// www. thueringen.de/de/tmsfg/aktuell/reden/27627/uindex.html [in German].

Zitate zum Thema «Macht». Retrieved from http:// www.zitate-online.de/thema/macht [in German].

Zitate, Sprüche. Retrieved from http:// https://www.zitate.de/search?in=Quotes\&q=Macht [in German].

\section{References}

Gaidutchenko, L.V. (2008) Deryvatsiine pole konzeptu Macht (vlada) v nimezkomovnii kartyni svitu [Derivation area of concept Macht (power) in German world picture]. Problemy semantyky, pragmatyky ta kognityvnoi lingvistyky - Problems of semantics, pragmatics and cognitive linguistics, 13, 74-80 [in Ukrainian].

Sasiekin, S. (2012). Psycholinguistychni universaliii perekladu khudozchniogo tekstu [Psycholinguistic universals of artistic text translation]. Lutsk: Volynskyi natsionalnyi universytet imeni Lesi Ukrainky [in Ukrainian].

Lakoff, G., \& Johnson, M. (2008). Metaphory kotorimi my zhyviom [Methaphors we live by]. Moscow: LKI [in Russian].

Magun, V.S., \& Rudniev, M.G. (2007). Zhysnenyiie tsennosti naseleniia Ukrainy $v$ jevropeiskom contekste [Life values of Ukrainian population in europien context]. Retrieved from https://polit.ru/research/\%202007/07/16/10values.html\%20\#_ftn5 [in Russian].

Petrenko, V. (1997). Osnovy psichosemantiki [Basics of Psychosemantics]. Moscow: MGU [in Russian].

Popova, S.D., \& Sternin, I.A. (2007). Kognitivnaia lingvistika [Cognitive Linguistics]. Moscow: AST. Vostok-Zapad [in Russian].

Spiridonova, L. (2015). Asotsiatyvnyi eksperyment yak zasib doslidzheniia obrasu svitu [Associative experiment as a mean of world image research]. Nauka $i$ osvita - Science and education, 1, 152-158 [in Ukrainian].

Sternin, I.A. (2017). Leksikographicheskoiie predstavleniie psicholingvisticheskogo snacheniia slova [Lexicographic imagination of psycholinguistic word meaning]. Vestnik RUDN - RUDN Messenger, 15(2), 204-214. https://doi. org/10.22363/2313-2264-2017-15-2-204-214 [in Russian].

Hoffman, P., Lambon, R., Matthew, A.R., \& Timothy, T. (2013). Semantic diversity: A measure of semantic ambiguity based on variability in the contextual usage of words. Behavior Research Methods, 45(3), 718-730. https://doi.org/10.3758/ s13428-012-0278-x 
Mohler, P., \& Wohn, K. (2005). Persönliche Wertorientierungen im European Social Survey. ZUMA-Arbeitsbericht, 2005(01), 21 [in German].

Ober, B.A., \& Shenaut, G.K. (2006). Semantic memory. In M.J. Traxler \& M.A. Gernsbacher (Eds.), Handbook of Psycholinguistics (pp. 403-455). New York: Academic Press. https://doi.org/10.1016/B978-012369374-7/50012-2

Richter, M. (2005). Kommunikative Konflikthandhabung. Wirtschaftskybernetik und Systemanalyse. Band 24. Interkulturelle Kooperation. Wissenschaftliche Jahrestagung der Gesellschaft für Wirtschafts- und Sozialkybernetik vom 6. und 7. Oktober 2005 in Greifswald. Berlin: Duncker \& Humbolt [in German].

Resch, B. (1991). Kulturstandards lernen und vermitteln. Kulturstandards in der interkulturellen Begegnung (pp. 71-102). Saabrücken: Breitenbach [in German].

Schwartz, S.H., \& Bilsky, W. (1990). Toward a Theory of the Universal Content and Structure of Values: Extensions and Cross-Cultural Replications. Journal of Personality and Social Psychology, 58, 878-891. https://doi.org/10.1037/00223514.58.5.878

Thomas, A. (1993). Kulturvergleichende Psychologie. Göttingen: Hogrefe

Wander, K. Deutsches Sprichwörter-Lexikon. Ein Hausschatz für das deutsche Volk. Retrieved from https://www.zeno.org/Wander-1867/A/Macht?hl=macht [in German].

Willis Witze. Politiker. Retrieved from https://www.willis-witze.de/Politiker-Witze/ Uebersicht-50,1.html [in German].

Witze zum Thema «Politik und Gesellschaft». Retrieved from http:// www.hahaha.de/ witze/politik-gesellschaft [in German].

Yang, Xu, Malt, C.B., \& Srinivasan, M. (2017). Evolution of word meaning through metaphorical mapping: Systematicity over the past millennium. Cognitive Psychology, 96, 41-53. https://doi.org/10.1016/j.cogpsych.2017.05.005

Zeh, K. Christliche Werte - Menschliche Politik. Retrieved from http:// www. thueringen.de/de/tmsfg/aktuell/reden/27627/uindex.html [in German].

Zitate zum Thema «Macht». Retrieved from http:// www.zitate-online.de/thema/macht [in German].

Zitate, Sprüche. Retrieved from http:// https://www.zitate.de/search?in=Quotes\&q=Macht [in German].

\begin{abstract}
АНОТАЦІЯ
Актуальність дослідження визначила необхідність вивчення особливостей контекстуальної реалізації концепту "МАСНТ» у мовно-культурному ареалі німців шляхом залучення результатів вільного асоціативного експерименту та контекстуального аналізу паремій та афоризмів, що дасть нам можливість виявити ціннісні настанови та пріоритети жителів ФРН.
\end{abstract}

Метою статті $\epsilon$ виявлення психолінгвістичних особливостей концепту "МАСНТ» у мовно-культурному просторі німців на основі зіставлення результатів контекстуального аналізу паремій та афоризмів $і$ вільного асоціативного експерименту.

Опис мовного матеріалу зумовив застосування таких методів дослідження: метод семантико-когнітивного моделювання концептів дозволив визначити макромоделі та описання фреймової моделі організації концепту "МАСНТ», 
яка полягає у ланцюжці концепту «MACHT», макрофррейму "MACHT UND GESELLSCHAFT» ma субфреймів "MACHT UND DAS POLITISCHE», "MACHT UND DAS SOZIALE» «MACHT UND DAS HÄUSLICHE». Для вивчення психолінгвістичних особливостей контекстуальної реалізації концепту нами було використано методику вільного асоціативного експерименту.

Результат проведеного аналізу встановив, що концепт "МАСНТ» реалізується у мовно-культурному просторі німців у субфреймах "MACHT UND DAS POLITISCHE», "MACHT UND DAS SOZIALE» "MACHT UND DAS HÄUSLICHE», de типовий представник суб'єкта влади та владних відносин характеризується ціннісними можливостями керувати іншими, мати повагу, статки та певні соціальні характеристики, такі як: медичне страхування, сочіальна допомога у випадку безробіття, змога інтегрувати себе у суспільстві у статусі біжения, матері-одиночки або батька-одинака, мати право на відпустку та вільний час, право на сексуальну рівність. Також важливим тут є ціннісний показник індивіда, що формує аксіологічну категорію самоствердження та есплікується у реакціях вільного асоціативного експерименту в номінаціях та показниках власності, авторитету, збереження свого обличчя в очах громадськості та в побуті.

Висновки. Таким чином загальний образ прототипу ідеального суб'єкта влади мислиться етноспецифічним носієм німецької лінгвокультури у зв'язку з безпосередньою діяльністю суб'єкта влади, його комунікативною поведінкою, особистими рисами, необхідними для результативного здійснення влади, та зовнішнім виглядом та соціальним станом.

Ключові слова: лексема, семантика, концепт, влада, німецькомовна лінгвокультура, субфрейм, контекстуальна реалізація, вільний асоціативний експеримент.

\title{
Скляренко Олеся, Акимова Алина, Свириденко Оксана. Психолингвистические особенности контекстуальной репрезентации концепта "МАСНТ» в языковом и культурном пространстве немцев
}

\begin{abstract}
АННОТАЦИЯ
Актуальность исследования определила необходимость изучения особенностей контекстуальной реализации концепта «МАСНТ» в языковом и культурном ареале немцев путем привлечения результатов свободного ассоциативного эксперимента и контекстуального анализа паремий и афоризмов, что дало нам возможность определить ценностные установки и приоритеты жителей ФРГ.

Целью статьи является определение психолингвистических особенностей концепта "МАСНТ» в языковом и культурном пространстве немцев на основе сопоставления результатов контекстуального анализа паремий и афоризмов, а также используя свободный ассоциативный эксперимент. Описание языкового материала обусловило применение таких методов исследования: метод семантико-когнитивного моделирования концептов позволил определить макромодели и описание фреймовой модели организации концепта "МАСНТ»,
\end{abstract}


Психолінгвістичні особливості контекстуальної реалізацї̈...

которая заключается в чепочке концепта "МАCHT», макрофрейма "МАCHT UND GESELLSCHAFT» и субфреймов "MACHT UND DAS POLITISCHE», "MACHT UND DAS SOZIALE» "MACHT UND DAS HÄUSLICHE». Для изучения психолингвистических особенностей контекстуальной реализации концепта нами была использована методика свободного ассоциативного эксперимента.

Результат проведенного анализа определил, что концепт "МАСНТ» реализуется в языковом и культурном пространстве немцев в субфреймах «MACHT UND DAS POLITISCHE», "MACHT UND DAS SOZIALE» "MACHT UND DAS HÄUSLICHE», где типичный представитель субъекта власти и властных отношений характеризуется ценностными возможностями управлять другими, иметь уважение, состояние и определенные социальные характеристики, такие как: медицинское страхование, социальная помощь в случае безработицы, возможность интегрировать себя в обществе в статусе бежениа, материодиночки или отца-одиночки, иметь право на отпуск и свободное время, право на сексуальное равенство. Также важным здесь является ценностный показатель индивида, который формирует аксиологическую категорию самоутверждения и эксплицируется в реакциях свободного ассоциативного эксперимента в номинациях и показателях собственности, авторитета, сохранения своего лица в глазах общественности и в быту.

Заключение. Поэтому, общий образ прототипа идеального субъекта власти мыслится этноспецифическим носителем немецкой лингвокультуры в связи с непосредственной деятельностью субъекта власти, его коммуникативного поведения, особенными чертами, необходимыми для результативного совершения власти и совершения власти, а также внутренним взглядом и социальным статусом.

Ключевые слова: лексема, семантика, концепт, власть, немецкоязычная лингвокультура, субррейм, контекстуальная реализация, свободный ассоциативный эксперимент. 